\title{
25 Research Soure \\ Physical and chemical modifications of cellulose fibers for food packaging applications
}

\section{Shahab Saedi}

Kunsan National University

Coralia V. Garcia

Keimyung University

Jun Tae Kim

Keimyung University

Gye Hwa Shin ( $\nabla$ winnie19@kunsan.ac.kr)

Kunsan National University https://orcid.org/0000-0002-1891-9053

\section{Research Article}

Keywords: cellulose fibers, food packaging, barrier properties, mechanical properties

Posted Date: March 9th, 2021

DOI: https://doi.org/10.21203/rs.3.rs-223314/v1

License: (9) This work is licensed under a Creative Commons Attribution 4.0 International License. Read Full License

Version of Record: A version of this preprint was published at Cellulose on July 26th, 2021. See the published version at https://doi.org/10.1007/s10570-021-04086-0. 


\section{Abstract}

Cellulose fibers have gained considerable interest for use as gas barrier and reinforcing fillers in food packaging materials because of their interesting properties including biodegradability, low density, nontoxicity, and low cost. Although the modification of cellulose nanomaterials for reinforcing applications has been reviewed in the literature, they suffer from a lack of comparative results, and the modifications related to food packaging applications have not been covered yet. This study reviews physical and chemical methods used to improve oxygen and water barrier properties, water uptake, mechanical strength, and transparency of different food packaging films of cellulose nanomaterials and provides comparative results. Heat treatment, esterification, and tempo-mediated and periodate oxidation are the most common methods for the improvement of the barrier properties of free-standing, bilayer, and composite films prepared from cellulose nanomaterials. Modification using silane compounds is a wellestablished method for improving the mechanical properties of cellulose fibers and polymer composite films.

\section{Introduction}

About $40 \%$ of the food produced every year gets spoiled (Wang et al. 2018); however, appropriate packaging can decrease the spoilage rate substantially. Accordingly, to preserve the quality and safety of food during distribution and storage and to provide end-use convenience, both suppliers and distributors increasingly use more food packaging (Vilarinho et al. 2018). The control of the transmittance of oxygen and moisture between food and its environment is one of the most important factors in preserving the quality of food, extending the shelf life, and preventing food spoilage (Hubbe et al. 2017; Wang et al. 2018). Glass and metal exhibit high oxygen and moisture barrier properties. However, there are some disadvantages associated with the use of these materials for food packaging applications, namely their high density that increases the transportation expenses and the high cost of the material itself (Ferrer et al. 2017; Wang et al. 2018). Compared to glass and metal, plastics are much lighter and cheaper. Hence, about $40 \%$ of the produced plastic is used for food packaging applications (Vilarinho et al. 2018). Currently, petroleum-based plastics are the most used packaging materials because of their versatility and excellent properties for packaging (Qasim et al. 2020). Even though most plastics possess high water vapor barrier properties, their poor oxygen barrier properties result in the eventual loss of food quality (Saallah et al. 2020; Wang et al. 2018). Thus, decreasing the oxygen permeability of these materials can increase the shelf life of the packaged food and prevent wastage. Although plastics can be laminated and coated with metal foils to decrease their oxygen permeability, these approaches limit the recycling of plastic wastes and hinder the degradation of biodegradable packaging (Wang et al. 2018). Owing to the low intrinsic oxygen permeability of different types of plastics, cellulose fibers have gained much attention as nanofillers or barrier layers to improve their oxygen barrier properties. The use of cellulose fibers as nanofillers improves the mechanical properties of the resulting nanocomposites and in the case of biodegradable packaging materials, which usually show high water vapor permeability, also improves moisture barrier properties (Saallah et al. 2020; Wang et al. 2018). When used as nanofillers for 
food packaging materials, cellulose fibers show advantages including safety, lightweightedness, biodegradability, renewability, non-abrasiveness, abundance, and high transparency (Ferrer et al. 2017; Mohit \& Arul Mozhi Selvan 2018). Hence, in combination with biodegradable plastics like polylactic acid (PLA) (Espino-Pérez et al. 2013), they can provide a safe and fully biodegradable composite with enhanced barrier and mechanical properties and negligible loss of transparency. Besides, cellulose fibers can be prepared from different sources including food wastes and agricultural by-products, allowing for the production of a high value-added product from a free or very low-cost source (Seo et al. 2018).

Despite the many advantages of cellulose fibers as fillers and barrier layers for improving the mechanical strength and barrier properties of food packaging materials, they have certain drawbacks including low compatibility with most plastics (Vilarinho et al. 2018), high hydrophilicity (Hubbe et al. 2017), and low thermal stability (Ben Azouz et al. 2012). Low compatibility between the cellulose fibers and hydrophobic matrix restricts their dispersion in the polymer matrix and decreases the mechanical strength and barrier properties of the resulting composites. The high hydrophilicity of the fibers results in high adsorption of water vapor, which decreases their oxygen barrier properties and limits their use in the presence of moist foods (Ben Azouz et al. 2012; Hubbe et al. 2017; Vilarinho et al. 2018). Therefore, modification of cellulose fibers is recommended for food packaging applications. Appropriate modification of cellulose nanomaterials should improve one or more properties of the final product including oxygen and water vapor barrier properties, mechanical strength, and thermal stability. In this regard, physical and chemical modifications have been performed to improve the compatibility of cellulose fibers with hydrophobic polymeric matrixes, decrease their hydrophilicity, and increase their thermal stability (Kargarzadeh et al. 2018; Vilarinho et al. 2018). Any improvement in polymer-fiber interfacial adhesion results in better dispersion in the polymer matrix, improves oxygen and water vapor barrier properties, and enhances the mechanical strength of the final food packaging material. Hence, modification of cellulose fibers for using them in food packaging applications opens new horizons for developing sustainable, green, and biodegradable materials, and can be a milestone in the journey of building an environment without plastic wastes.

Although the modification of cellulose nanomaterials has been reported in literature, previous reviews have been limited to reinforcing applications of cellulose nanomaterials, but the importance of these modifications for improving barrier properties has not been discussed. Even though most review articles discuss the mechanisms and effects of the physical and chemical modifications on the mechanical properties in detail, they do not provide the comparative results of the mechanical tests. The purpose of this review was to discuss the effects of different physical and chemical treatments of cellulose fibers on the most important parameters for food packaging applications, namely the oxygen and water vapor barrier, water uptake, mechanical strength, and the transparency of the final composite materials. In this review, the structure of plant and cellulose fibers and their preparation methods are explained briefly. Also, this paper aims to briefly explain the principles behind different cellulose modification methods and the mechanisms of the reactions involved in the treatments. The importance of the oxygen and water vapor barrier ability and the mechanical strength of food packaging materials are discussed. The effects of 
different treatments on the water vapor and oxygen barrier properties and mechanical strength are also compared.

\section{Plant Fiber And Cellulose Nanoparticles}

Plant fibers can be classified depending on the part they are obtained from: straw fibers (corn, rice, and wheat), bast fibers (flax, hemp, jute, kenaf, and ramie), wood fibers (softwood and hardwood), leaf fibers (abaca and sisal), grass fibers (bagasse and bamboo), and seed fibers (coir, cotton, and kapok) (Azeredo et al. 2017; Kim \& Netravali 2010a, Mohit \& Arul Mozhi Selvan 2018; Zhang et al. 2020). Depending on the plant type, extraction method, and the place in which the plant is cultivated, fibers are composed of varying amounts of cellulose, hemicellulose, lignin, pectin, waxes, and inorganic compounds (ash). The physicochemical properties of plant fibers are influenced by the species, chemical composition, crystallinity, microfibril angle, and presence of defects (Kim \& Netravali 2010b \& 2011; Lee et al. 2017; Zhang et al. 2020). The hierarchical microstructure of plant fibers and chemical structure of cellulose is shown in Fig. 1.

Inter and intra hydrogen bonding as a special feature of cellulose plays a key role in most characteristics of this polysaccharide such as low solubility, high crystallinity, and low compatibility with other non-polar polymers (Habibi 2014; Islam et al. 2018; Vilarinho et al. 2018). Plant fibers contain various amounts of cellulose embedded as microfibrils in a matrix of hemicellulose and pectin. Cellulose microfibrils possess crystalline and amorphous regions. Tight interchain hydrogen bonding between a bundle of cellulose chains creates a crystalline region of microfibrils, which is inaccessible for most solvents and reagents (Lee et al. 2017; Mohit \& Arul Mozhi Selvan 2018; Vilarinho et al. 2018) (Fig. 1).

Different mechanical, chemical, and biological treatments on plant fibers can produce various micro and nanosized cellulosic products, namely cellulose microcrystalline (CMC), cellulose nanofibrils (CNFs), and cellulose nanocrystals (CNCs) (Kargarzadeh et al. 2018; Lee et al. 2017; Vilarinho et al. 2018). Figure 1 shows the flowchart of the production of CMC, CNCs, and CNFs from plant fibers as well as schematic representations and SEM images of these structures. To avoid ambiguity about the different terms used in cellulose technology, standard terms and appropriate definitions have been proposed by the Technical Association of the Pulp and Paper Industry (TAPPI) (Fig. 1) (Kargarzadeh et al. 2018).

\section{Barrier And Mechanical Properties Of Food Packaging Materials}

\subsection{Oxygen barrier properties}

Lipid oxidation is responsible for most of the deterioration of foodstuffs (Lu et al. 2018). Also, the presence of oxygen in the food environment increases the growth rate of bacteria and unwanted harmful reactions that accelerate the spoilage of food. Hence, besides protecting food from physical damage and contact with dust and other pollutants, food packaging should protect food from deterioration reactions by preventing the oxygen transfer between the interior part of the packaging and surrounding atmosphere 
(Arrieta et al. 2017). In terms of oxygen barrier properties, based on a rough classification suggested by Wang et al. (2018), polymeric packaging materials can be classified into five categories including poor, low, medium, high, and very high. The most common non-biodegradable (PP, PE, and PS) and biodegradable (PLA and PHA) polymers have poor oxygen barrier properties that hardly meet the requirements for packaging foodstuffs like fresh meat, cheese, and instant coffee. Although some biodegradable polymers like PVA have high oxygen barrier properties (due to their hydrogen bonding) in dry conditions, their high water absorption capacity leads to a significant drop of oxygen barrier properties in moist conditions, which restricts their use for most food applications (Wang et al. 2018). High oxygen barrier cellulose nanomaterials (Fig. 1) have been used to make composite films using impermeable commercial polymers like PVC and PVA, and have also been used as coatings for low oxygen barrier films (Fig. 2) (Hubbe et al. 2017; Vilarinho et al. 2018; Wang et al. 2018). However, when used as a thin layer, the high hydrophilicity of cellulose nanomaterials restricts their use to dry foods and dry conditions. Due to the abundance of hydroxyl groups on the surface of cellulose nanomaterials, their homogeneous dispersion in the polymer matrix, which is crucial for effective oxygen barrier action, is a challenge. Low compatibility with packaging materials results in low interfacial adhesion between polymer and filler and creates cavities for the diffusion of oxygen molecules. Also, the adsorption of water results in the loss of the oxygen barrier ability of cellulose fibers. Hence, for taking full advantage of these fibers as fillers by improving the oxygen barrier properties of polymers, the following issues must be addressed: i) their high tendency to agglomerate (due to their surface hydroxyl groups), ii) low compatibility with commercial packaging materials, and iii) high hydrophilicity and water absorption capacity (Dufresne 2017; Kargarzadeh et al. 2018; Liu et al. 2019; Mohit \& Arul Mozhi Selvan 2018).

\subsection{Water vapor permeability and water uptake}

The transfer of water vapor between food and the surrounding environment plays a crucial role in the shelf life of food products. In the case of fresh foods like vegetables and meat, it is important to avoid dehydration of the product, whereas dry foods like bread must be protected from the humidity of the air (Wang et al. 2018). Water vapor permeability (WVP) refers to the amount of water that transfers across the film per unit of area and time. As the thickness of the film and the water vapor pressure difference across the film are important factors in the amount of transmitted water, the water vapor flux must be normalized for these two variables. Hence, WVP can be expressed as

$$
\mathrm{WVP}=\mathrm{WVTR} \times \frac{x}{\Delta P}
$$

where WVTR is water vapor transmission rate $\left(\mathrm{g} / \mathrm{m}^{2} \cdot\right.$ day $), x$ is the thickness of the film $(\mathrm{m})$ and $\Delta P$ is the differential vapor pressure of water across the film $(\mathrm{Pa})$.

The improvement of barrier properties associated with the use of cellulose fibers as a filler is ascribed to the decrease of the diffusion of gases by creating a more tortuous path across the film (Ferrer et al. 2017; 
Hubbe et al. 2017; Wang et al. 2018). The use of cellulosic fibers in various matrices from water-soluble polymers like PVA (Pereira et al. 2014) to hydrophobic commercial polymers like PLA (Espino-Pérez et al. 2018) has been reported to decrease the WVP. However, the water sensitivity of films, which refers to the resistance of the film against water vapor, preserving its structure and avoiding swelling, can be affected by the presence of cellulose fillers. For most of the commercial hydrophobic polymers, water uptake can be a reliable test to evaluate the resistance of films against water. In terms of food freshness and shelf life, water vapor permeability is an important characteristic, especially for the packaging of wet food products like meat and vegetables (Azeredo et al. 2017). Although cellulose is not a water-soluble polymer and most of its hydroxyl groups are involved in intra- and inter-molecular interactions in the crystalline regions, the surface hydroxyl groups, and those groups in the amorphous region are able to hold a large amount of water. As the volume of cellulose or plant fibers increases as water is absorbed, the shape of the produced composites may change. Also, evaporation of adsorbed water at high temperatures or dry weather leads to the shrinkage of the reinforcing material and detachment between the filler and host polymer, resulting in a loss of mechanical strength. Furthermore, adsorbed water molecules can loosen the inter-molecular interactions between cellulose chains by disassociating the hydrogen bonding among them. Hence, the adsorption of water in a humid environment results in the plasticization of composites containing cellulose fibers and leads to a significant increase in oxygen permeability (Wang et al. 2020).

Thus, to preserve the oxygen and water vapor barrier properties as well as the dimensional stability and mechanical strength of food packaging, especially in a humid environment, and to avoid increasing the weight of the composite, modification of cellulose fibers should be carried out. Improvements in the interfacial interaction between the host polymer and fiber and decreased hydrophilicity of the incorporated fibers can enhance the barrier properties (Espino-Pérez et al. 2018) and decrease the swelling and water uptake (Chuayplod \& Aht-Ong 2018). Non-bonding modification of fibers with a hydrophobic material to shield the fiber, or reaction of surface hydroxyl groups with a coupling agent to reduce the accessible hydroxyl groups for adsorbing moisture, are approaches to overcome this problem. If a chemical bond between the filler and polymer can be formed through a coupling agent, the oxygen and water vapor barrier and mechanical properties of the prepared composite can be improved in both dry and wet conditions (Mishra et al. 2001). The results of modifications carried out to reduce the water uptake are shown in Table 1.

\subsection{Mechanical strength}

Tensile properties are the most studied aspect of composite films prepared using cellulose fibers. The high strength and stiffness of cellulose fibers and their high aspect ratio make them good candidates for reinforcing purposes. Besides, lightweightedness, transparency, and biodegradability are advantages of cellulose fibers in comparison with their traditional counterparts like glass and carbon fibers. Food packaging must have enough mechanical strength to resist handling damages and protect food items from damage during distribution. Hence, mechanical strength is one of the most important aspects of food packaging materials (Yu et al. 2014). Recently the application of cellulose fibers for improving the 
mechanical properties of food packaging materials like PLA (Shojaeiarani et al. 2019), and other petroleum-based thermoset polymers like PE (Ferreira et al. 2019) and PP (Kahavita et al. 2019) has gained a lot of attention. Despite the many advantages of cellulosic fibers as a reinforcing filler, they suffer from some serious drawbacks including low compatibility with commercial polymers, low dispersibility in commonly used non-polar matrices like PLA, and high moisture adsorption, which leads to the loss of mechanical properties with time. The low compatibility of cellulose nanoparticles with most of the commercial food packaging polymers results in low interfacial adhesion between the filler and the polymer and diminishes the stress transfer from the polymer to the cellulose filler, weakening the mechanical strength of the prepared composites. The detachment of the cellulose fillers and polymer matrices increases the accessible surface hydroxyl groups for the adsorption of moisture and leads to the loss of mechanical strength and barrier properties, which may in turn affect food quality. Thus, physical and chemical modifications that improve the compatibility of the cellulose filler and polymer matrix enhance the mechanical and barrier properties of the packaging materials and increase the shelf life of foods (Mohit \& Arul Mozhi Selvan 2018; Vilarinho et al. 2018; Zhang et al. 2020). A comparison of the effects of these modifications in terms of tensile strength, Young's modulus, elongation at break, and tensile strain are shown in Table 2.

\section{Physical Modification Of Cellulose Fibers}

In this review, physical methods refer to those treatments that do not use any chemical substance to induce a change or modification on the surface of the fiber. These methods include plasma and corona discharges, gamma irradiation, and application of UV light. As physical modification techniques do not consume hazardous chemicals, they are the eco-friendlier methods (Ragoubi et al. 2012).

\subsection{Heat treatment}

In this method, cellulosic fibers are heated in a convection oven to remove impurities, increase the oxygen/carbon ratio, and enhance the acidity of the cellulose surface. Heat treatment increases the crystallinity of the fiber and enhances its mechanical properties (Cao et al. 2007). Heat treatment was reported to decrease the porosity and oxygen permeability of a CNF film (Xia et al. 2018). Sharma et al. (2014) used heat treatment to increase both the barrier and mechanical properties of a CNF film.

\subsection{Plasma treatment}

Plasma contains a mixture of reactive species including free radicals, electrons, and heavy particles that could be used for the modification of fibers or the surface of polymers and films. The most commonly used types of plasma for the surface modification of fibers are low pressure, low temperature, atmospheric glow discharge (AGD), and atmospheric pressure plasma jet (APPJ) (Kalia et al. 2013). The type of gas, gas pressure and flow rate, and the applied power, and treatment time are variables that can be controlled to induce the desired effect on the surface of the polymer or fiber. However, due to the risk of the degradation of the cellulosic material in the plasma environment, it must be applied in a controlled manner (Sarikanat et al. 2016). Due to the high incompatibility between the microfabricated cellulose and 
PLA, activation of the polymer surface by atmospheric plasma was performed to fabricate a fully biodegradable bilayer system for food packaging applications (Meriçer et al. 2016). Lu and co-workers (Lu et al. 2018) used cold plasma for coating biaxially-oriented polypropylene/low-density polyethylene (BOPP/LDPE) with a layer of nanofibrillated cellulose to improve the oxygen barrier properties of the packaging material.

\subsection{Corona modification}

Applying high voltage to a bundle of sharp tip electrodes produces a corona in which the plasma is formed only on the tips. The corona treatment is one of the most interesting methods for the surface oxidation activation of cellulose fibers used in polyolefin composites (Mohit \& Arul Mozhi Selvan 2018). In this method, both the cellulose filler and matrix polymer can be modified by corona treatment, although the modification of the filler generates more pronounced effects. Corona treatment using air increases the oxygen/carbon ratio on the surface of the fibers and enhances their polarity and wettability. Also, the etching effect of the corona treatment enhances the mechanical anchorage and interfacial adhesion between the filler and the matrix polymer and leads to improved mechanical and barrier properties (Ragoubi et al. 2010).

\subsection{UV modification}

UV radiation enhances the formation of carbonyl groups on the surface of wood and natural fibers, thus improving the fiber surface polarity (Mohit \& Arul Mozhi Selvan 2018). Moreover, UV treatment can also lead to crosslinking between the neighboring cellulose molecules, enhancing the strength and barrier properties of the treated fiber (Zaman et al. 2009).

\subsection{Gamma irradiation}

High-energy gamma irradiation is a suitable treatment to induce physicochemical changes like crosslinking, decomposition, and unsaturation, thereby strengthening and hardening the polymeric material (Mohit \& Arul Mozhi Selvan 2018). Cellulose can interact with gamma radiation through the Compton scattering phenomenon in which trapped macrocellulosic radicals are formed due to the rapid localization of energy within cellulose. The creation of active sites on the surface of the cellulose fiber enhances the bonding between the fiber and the matrix (Zaman et al. 2010). For instance, Khan et al. (2013) used gamma irradiation to improve both the mechanical and barrier properties of poly(caprolactone) (PCL)/nanocrystalline cellulose (NCC).

\section{Chemical Modification Of Cellulose Fibers}

Here, chemical modification refers to methods that use one or more chemical substances to change the physicochemical properties of cellulose particles. As shown in Fig. 1, in each cellobiose moiety of cellulose, there are two secondary $\left(C_{2}\right.$ and $\left.C_{3}\right)$ and one primary alcohol groups which could be subjected to different chemical reactions including oxidation and substitution (Kargarzadeh et al. 2018). Treatment of cellulosic fibers using chemicals can be classified into two categories, one that involves the chemical 
bonding between matrix and filler and one that does not. However, both methods can improve the mechanical and barrier properties of the composites.

\subsection{Non-bonding modification \\ 5.1.1. TEMPO-mediated oxidation}

The goal of TEMPO-mediated oxidation of cellulose is to introduce aldehyde and carboxyl functional groups to the surface of cellulose fibers to improve their mechanical properties. In this method, sodium hypochlorite is added to aqueous cellulose suspensions at $\mathrm{pH} 10-11$ in the presence of TEMPO and sodium bromide. The reaction is carried out at room temperature (Fig. $3 \mathrm{a}$ ). It is believed that the aldehyde groups can form a covalent bond with cationic resin and enhance the final properties of the composite. The formation of a covalent bond between microfibrils through hemiacetal and acetal linkages improves the mechanical strength of fibers and decreases their water absorption capacity. The possible mechanism behind this phenomenon is shown in Fig. 3b (Lal \& Mhaske 2019). Besides the improvement of the mechanical properties of cellulose fibers in free-standing CNF and CNC films, the creation of carboxylic groups on the surface of fibers can enhance the mechanical and barrier properties of the composite by reacting with their functional groups (Lai et al. 2014). Sirviö et al. (2014) used TEMPOmediated oxidized CNC to prepare free -standing oxygen barrier films.

\subsubsection{Periodate oxidation}

Oxidation of hydroxyl groups to aldehyde can be carried out using periodate. As in the TEMPO-mediated oxidized cellulose, aldehyde groups can induce crosslinking between the cellulose chains and improve the barrier properties of the film. Cellulose was converted to dialdehyde with lithium chloride (LiCl)assisted sodium meta-periodate $\left(\mathrm{NaIO}_{4}\right)$ oxidation by Visanko et al. (2015). These researchers used the oxidized cellulose to prepare butylamino-functionalized cellulose nanocrystal films with excellent oxygen barrier ability at high relative humidity. Periodate was also used to make self-cross-linked fibrillated cellulose to improve the barrier and water uptake properties of CNF films (Larsson et al. 2013). Plappert et al. (2018) used periodate for the synthesis of 2,3-dialdehyde cellulose (DAC) with a high degree of oxidation to prepare a very hydrophobic cellulose film with remarkable oxygen barrier properties even at high relative humidity.

\subsection{Bonding modification 5.2.1. Coupling agents}

Coupling agents are defined as materials that can form a covalent bond with the fiber and at the same time can connect to the polymer matrix (Abushammala \& Mao 2019). In this way, they can improve the interfacial adhesion between the filler and polymer matrix, enhance stress transfer, and improve both mechanical and barrier properties (Mohit \& Arul Mozhi Selvan 2018). Due to the presence of a high density of hydroxyl groups which can be subjected to various substitution reactions, the use of coupling 
agents is one of the most adopted and studied approaches for improving polymer-filler interfacial interaction (Dufresne 2017; Habibi 2014). Coupling agents can also improve the service time of composite materials. In fact, without using coupling agents, many high-performance plastic products would not exist. In the case of composites containing cellulose fiber, this modification can reduce the water uptake of the composite and increase the service time in the wet conditions of the food environment as well as preserve the oxygen barrier activity of cellulose nanomaterials. Although different classes of coupling agents have been introduced, most of them give only short-term improvement. Organo-silanes (R-Si- $(\mathrm{OR})_{3}$ ) are the most effective, commercially available, and low-cost coupling agents. They are widely used for modifying the surface properties of inorganic fillers and their durability has been proved. Silane possesses hydrolysable groups that make it possible to attach to the surface of glass or cellulose fibers, and an organic portion $(R)$ which is responsible for the improvement of the compatibility between the filler and polymer matrix and for decreasing the hydrophilicity of the cellulose fibers. Coupling agents may contain some highly reactive functional groups like amine, vinyl, mercapto, methacryloxy, and polysulfide that can bond with the host polymer for better stress transfer (Thakur et al. 2014). In the presence of moisture, silane reacts with surface cellulosic hydroxyl groups and attaches to the fiber through a covalent bond (Fig. 3c). Coupling agents also improve the interfacial adhesion between fiber and polymer, and they can impart adequate functional groups onto the surface of fibers to participate in the polymer chain growth and provide an active site for the polymer grafting reaction (Demir et al. 2006). Selulosa-Polivinilklorida et al. (2015) proposed a reaction (Fig. 3d) between the amino silanemodified cellulose fiber and polyvinyl chloride. Amino silane-modified cellulosic fibers can also react with the carbonyl group of some polymers like polycarbonates through an amidation reaction and form an amide covalent bond as displayed in Fig. 3e (Threepopnatkul et al. 2009). Radical species that are generated on the surface of polyolefins due to the thermal oxidation and subsequent peroxide decomposition can react with the $\pi$ bond of silane and form a covalent bond with the modified fiber (Fig. 3f) (Abdelmouleh et al. 2007). In an attempt to reduce the WVTR of PLA/BC, Somord et al. modified BC using 3-(trimethoxysilyl) propyl methacrylate (Somord et al. 2018), resulting in enhanced water vapor barrier properties. As mentioned before, coupling agents are not limited to silane compounds, and different chemicals can provide different functional groups to connect with both the cellulosic filler and polymer matrix (Virtanen et al. 2014).

\subsubsection{Esterification}

Acetylation is a well-studied esterification reaction of cellulose fibers. Fibers become more hydrophobic when acetylated due to the involvement of surface hydroxyl groups, thus their resistance against humidity increases. For this reaction, cellulose fibers are treated with acetic anhydride in the presence of a catalyst (Fig. $3 \mathrm{~g}$ ). Acetylation enhances the interfacial adhesion between the fiber and the polymer matrix and decreases the water uptake of the prepared composite. This modification improves the mechanical properties and resistance of the final composite against moisture (Shojaeiarani et al. 2019). An esterification reaction was used to modify CNC with phenylacetic acid (PhAA) and hydrocinnamic acid (BzAA). The modified CNC improved the water vapor and oxygen barrier properties of PLA/CNC films (Espino-Pérez et al. 2018). An esterification reaction with a diacid can lead to the crosslinking of cellulose 
fibers. Crosslinking a nanocellulose film with citric acid significantly reduced the oxygen and water vapor permeability (Herrera et al. 2017). Sehaqui et al. (2014) used an esterification reaction to decrease the hydrophilicity and moisture uptake of a CNF film.

\subsubsection{Modification using isocyanates}

Aliphatic and aromatic mono and di-isocyanates have been used for the modification of cellulose for a long time as they can act as a surface modifier and conjugating material to graft a variety of molecules and polymers to the surface of cellulosic materials. Depending on the type of required modification, mono or diisocyanate can be employed through one of the scenarios represented in Fig. 3. Monoisocyanates are generally used to hydrophobize the cellulose fibers, improve their compatibility with nonpolar thermoplastics like PLA, and increase the mechanical and water vapor permeability (WVP) of the resulting films (Espino-Pérez et al. 2013) (Fig. 3h). Di-isocyanates can be used to bind functional groups onto the nanocellulose surface or to protect it during the processing of thermoset matrices. In this case, one of the isocyanates reacts with nanocellulose and the other one can react with a functional polymer (Fig. 3i). Using isocyanates has resulted in substantial improvements in the interfacial adhesion and mechanical properties of composites (Pinheiro et al. 2017).

\subsubsection{Polymer grafting}

The modification of cellulose and plant fibers using small coupling agents and other methods may not result in the expected improvement in mechanical and barrier properties. Hence, the grafting of a long chain polymer for improving barrier and mechanical properties has been investigated. Two main strategies, called "grafting from" and "grafting to" have been employed to graft a modifying polymer to the surface of fibers (Saedi et al. 2014; Xu et al. 2014).

In the "grafting from" strategy, the surface of fibers is pre-functionalized with an initiator (e.g., radicals) in the presence of a monomer, the polymerization reaction takes place, and the final polymer forms on the surface of the fiber. In the "grafting to" strategy, a previously synthesized polymer is grafted to the fiber surface directly (Le Gars et al. 2020). For these approaches, a variety of methods like ring-opening polymerization (ROP) (Fang et al. 2019) and atom transfer radical polymerization (ATRP) (Fig. 3j) (Le Gars et al. 2020) have been employed. The ROP method was used by Fang et al. (2019) to graft LA onto the surface of CNC to improve the oxygen resistance and mechanical properties of polyurethane films. Ambrosio-Martín et al. (2015) modified bacterial cellulose nanowhiskers (BCNW) by grafting lactic acid oligomers (OLLA) to improve the mechanical properties and oxygen and water barrier ability of PLA/BCNW composite films. In another study, the mechanical and oxygen barrier properties of PLA/BCNW composite films were improved by grafting poly (glycidyl methacrylate) (PGMA) onto BCNW (Martínez-Sanz et al. 2013). The free radical polymerization strategy was used by Song et al. (2014) to graft butyl acrylate onto CNF for making a PLA/CNF composite film with high water vapor barrier properties. Malleated polyolefins are widely used to modify the surface of cellulosic fibers for use as reinforcement in nonpolar matrices. The reaction between cellulose and malleated (Fig. 3k) and acrylic 
acid-modified polyolefins (Fig. 3I) like PP and PE is a common way to graft polyolefins onto cellulose fibers (Rout et al. 2001).

\subsection{Miscellaneous}

In addition to the above-mentioned chemicals and methods, improvements of the mechanical, thermal, water uptake, and barrier properties of cellulose fibers using other chemicals like surfactants (Fortunati et al. 2012), permanganate (Sreekumar et al. 2009), and amino silicone oil (He et al. 2015) have been reported. Arrieta et al. (2014) and Fortunati et al. (2012) used surfactants for the modification of CNC to improve the mechanical and water vapor and oxygen barrier properties of PLA/CNC nanocomposite films. Benzoylation of cellulose fibers can decrease the thickness of fibers, and the introduction of a benzyl ring to the surface of a fiber can also improve the interfacial adhesion. The presence of a benzyl ring on the surface of a fiber increases the ability of the fiber to connect with active sites of the polymer matrix (Fig. 3m) (Sreekumar et al. 2009).

\section{Modifications For Increasing Heat Resistance}

Cellulose fibers show disadvantages including poor compatibility with most synthetic polymers, high moisture absorption capacity, and low thermal stability. As the molding temperature of most thermoplastics is higher than the decomposition temperature ranged of cellulosic fibers $\left(170-200^{\circ} \mathrm{C}\right)$, the molding process of composites containing cellulose and plant fibers leads to the formation of tar-like pyrolysis products due to the presence of resin acids and hydrolysable acetyl groups of cellulose (Sain et al. 1993). In the case of cellulose nanocrystals (CNC), it is believed that the presence of sulfate groups, formed during the preparation of CNC using sulfuric acid, is responsible for the low thermal stability of this filler (Dufresne 2017). Hence, there have been many efforts to solve the problem of low thermal stability of CNC. Treating CNC with sodium hydroxide or hydrochloric acid can improve its thermal stability. However, acid treatment worsens the dispersion of CNC in the polymer matrix. On the other hand, surface modification of CNC can shield sulfate groups and improve thermal stability. Coating CNC with hydrophilic polymers like PEO (Fig. 4) (Ben Azouz et al. 2012), modification with coupling agents (De Menezes et al. 2009), and modification with thermostable boron compounds (Sain et al. 1993) can be used effectively to overcome the low thermal stability and at the same time improve the dispersibility of cellulose fillers in hydrophobic matrices, thus enhancing the mechanical and barrier properties of the composites.

\section{Conclusion and future perspective}

As more non-biodegradable materials and non-renewable resources are replaced with biodegradable and renewable ones, the use of cellulose fibers as reinforcing and barrier materials increases. These fibers can open new horizons of sustainable development because they can be produced from fruit and vegetable wastes and agricultural by-products. However, drawbacks such as low compatibility with most commercial polymers, high water uptake, and low thermal stability must be addressed. As shown in this review, the oxygen and moisture barrier properties of PLA, PE, and PP, which are extensively used for food 
packaging applications, have been improved by using cellulose nanomaterials. Thus, a lot of effort has been dedicated towards enhancing the compatibility between cellulose nanomaterials and these polymers, and to improve the mechanical and oxygen and water barrier properties of their composites. Various physical and chemical methods have been developed to improve the mechanical and barrier properties of composites prepared using cellulose fibers. As physical treatments do not use hazardous chemicals, they are the eco-friendliest options. However, application of these methods for modification of cellulose fibers is restricted due to their limitations and minor effects on the fiber surface. Heat treatment is the most widely used physical method for improving the barrier properties of free-standing and bilayer films prepared from cellulose nanomaterials. This method can improve the oxygen barrier properties of cellulose nanomaterials up to $80 \%$. Oxidation of surface hydroxyl groups of cellulose nanomaterials using periodate and TEMPO are common chemical modifications that could be used for improving the oxygen barrier and mechanical properties of both free-standing and composite films of cellulose nanomaterials. The surface hydroxyl groups of cellulose nanoparticles provide active sites for various types of reactions and attaching various molecules and polymers. Esterification, polymer grafting, reaction with mono and diisocyanates, and reaction with silane compounds have been extensively employed to modify the properties of cellulose nanomaterials, improve their interaction with host polymers, and enhance the barrier and mechanical properties of the obtained composites. Coupling agents that possess two reactive sites and can connect to both cellulose nanoparticles and host polymer result in additional improvements in mechanical and barrier properties.

Although in many studies very promising improvements in mechanical, water uptake, and barrier properties were reported, the long-term applicability and cost for industrial-scale applications of these composites have been ignored. From a practical point of view, silane-coupling agents seem to be an appropriate modifying material as they are commercially available, can connect fibers and polymer matrix using a covalent bond, and guarantee a long-term improvement in the polymer-fiber interfacial adhesion, mechanical strength, and barrier properties. Hence, the effectiveness of any modification technique should be proved not only in the laboratory but also at the industrial scale.

The most studied aspect of cellulose fibers is their use as reinforcing materials. Considering that improvements in mechanical strength result from improvements in the interfacial interaction between the polymer and cellulose fiber, the effectiveness of this strategy on the barrier properties of the fiber and water resistance of the composites should also be evaluated. Cellulose nanomaterials are suitable candidates for improving the oxygen barrier properties of biodegradable plastics like PLA and PHA for food packaging applications. However, problems associated with their use like low compatibility, high hydrophilicity, and low thermal stability should be addressed using novel cost-effective chemical and physical modification methods.

\section{Abbreviations}




\begin{tabular}{|c|c|}
\hline A-1100 & Aminopropyltriethoxysilane \\
\hline A-189 & Mercaptopropyltrimethoxysilane \\
\hline $\mathrm{AC}$ & Acetic anhydride \\
\hline APS & $\mathrm{N}$-( $\beta$-aminoethyl)- $\gamma$-aminopropyltrimethoxysilane \\
\hline APTES & 3-aminopropyltriethoxysilane \\
\hline AS & (3-aminopropyl)-triethoxysilane \\
\hline $\mathrm{BC}$ & Bacterial cellulose \\
\hline BCNW & Bacterial cellulose nanowhiskers \\
\hline BIB & $\alpha$-bromoisobutyrylbromide \\
\hline BTDA & 3,3',4,4'-benzophenone tetracarboxylic dianhydride \\
\hline BZAA & Hydrocinnamic acid \\
\hline $\mathrm{CA}$ & Cellulose acetate \\
\hline $\mathrm{CF}$ & Cellulose fibers \\
\hline $\mathrm{CMC}$ & Carboxyl methyl cellulose \\
\hline CMF & Cellulose microfibrils \\
\hline $\mathrm{CNC}$ & Cellulose nanocrystal \\
\hline $\mathrm{CNF}$ & Cellulose nanofibrils \\
\hline CNW & Cellulose nanowhiskers \\
\hline Сус & Cyclohexanecarbonyl chloride \\
\hline DIC & 1,6-diisocyanatohexane \\
\hline EPTMAC & 2,3-epoxypropyl trimethylammonium chloride \\
\hline FC & Fibrous cellulose \\
\hline GMA & Glycidylmethacrylate \\
\hline HA & Hexylamine \\
\hline HDPE & High-density polyethylene \\
\hline HDMS & Hexamethyldisiloxane \\
\hline LDPE & Low-density polyethylene \\
\hline LLDPE & Linear low-density poly(ethylene) \\
\hline MAPP & Maleated polypropylene \\
\hline MDI & 4,4'-Methylenebis (phenyl isocyanate) \\
\hline MFC & Microfibrillated cellulose \\
\hline Myr & Myristoyl chloride \\
\hline OLLA & Lactic acid oligomer \\
\hline PCL & Poly( $\varepsilon$-caprolactone) \\
\hline $\mathrm{PE}$ & Polyethylene \\
\hline $\mathrm{PEO}$ & Polyethylenoxide \\
\hline PGMA & Poly(glycidylmethacrylate) \\
\hline PHA & Polyhydroxyalkanoates \\
\hline PhAA & Phenylacetic acid \\
\hline PLA & Polylactic acid \\
\hline PLLA & Poly(L-lactide) \\
\hline PMDETA & $\mathrm{N}, \mathrm{N}, \mathrm{N}^{\prime}, \mathrm{N}^{\prime \prime}, \mathrm{N}^{\prime \prime}$-pentamethyldiethylenetriamine \\
\hline PMMA & Polymethylmetacrylate \\
\hline $\mathrm{PP}$ & Polypropylene \\
\hline PP-g-MA & PP grafted with maleic anhydride \\
\hline PS & Polystyrene \\
\hline PVC & Polyvinylchloride \\
\hline Piv & Pivaloyl chloride \\
\hline Si69 & Bis(triethoxysilylpropyl) tetrasulfide \\
\hline Ste & Stearoyl chloride \\
\hline t-Buc & 4-t-Butylcyclohexanecarbonyl chloride \\
\hline
\end{tabular}




\section{Declarations}

\section{Acknowledgements}

This research was supported by Basic Science Research Program through the National Research Foundation of Korea (NRF) funded by the Ministry of Education (NRF-2019R1A4A1026423).

\section{Declaration of conflicting interests}

The authors declare no potential conflicts of interest.

\section{References}

1. Abdelmouleh M, Boufi S, Belgacem MN, Dufresne A (2007) Short natural-fibre reinforced polyethylene and natural rubber composites: effect of silane coupling agents and fibres loading. Compos Sci Technol 67:1627-1639. https://doi.org/10.1016/j.compscitech.2006.07.003

2. Abu-Thabit NY, Judeh AA, Hakeem AS, Ul-Hamid A, Umar Y, Ahmad A (2020) Isolation and characterization of microcrystalline cellulose from date seeds (Phoenix dactylifera L.). Int J Biol Macromol 155:730-739. https://doi.org/10.1016/j.jjbiomac.2020.03.255

3. Abushammala H, Mao J (2019) A review of the surface modification of cellulose and nanocellulose using aliphatic and aromatic mono-and di-isocyanates. Molecules 24:2782. https://doi.org/10.3390/molecules24152782

4. Ahmadi M, Behzad T, Bagheri R (2017) Reinforcement effect of poly (methyl methacrylate)-gcellulose nanofibers on LDPE/thermoplastic starch composites: preparation and characterization. Iran Polym J 26:733-742. https://doi.org/10.1007/s13726-017-0558-5

5. Ambrosio-Martín J, Fabra MJ, Lopez-Rubio A, Lagaron JM (2015) Melt polycondensation to improve the dispersion of bacterial cellulose into polylactide via melt compounding: enhanced barrier and mechanical properties. Cellulose 22:1201-1226. https://doi.org/10.1007/s10570-014-0523-9

6. Anžlovar A, Kunaver M, Krajnc A, Žagar E (2018) Nanocomposites of LLDPE and surface-modified cellulose nanocrystals prepared by melt processing. Molecules 23:1782. https://doi.org/10.3390/molecules23071782

7. Arrieta MP, Peltzer MA, López J, Peponi L (2017) PLA-based nanocomposites reinforced with CNC for food packaging applications: From synthesis to biodegradation. In Industrial applications of renewable biomass products (pp. 265-300) Springer

8. Arrieta MP, Fortunati E, Dominici F, Rayón E, López J, Kenny JM (2014) PLA-PHB/cellulose based films: Mechanical, barrier and disintegration properties. Polym Degrad Stabil 107:139-149. https://doi.org/10.1016/j.polymdegradstab.2014.05.010 
9. AzeredoHMC, Rosa MF, Mattoso LHC (2017) Nanocellulose in bio-based food packaging applications. Ind Crop Prod 97:664-671. https://doi.org/10.1016/j.indcrop.2016.03.013

10. Ben Azouz K, Ramires EC, Van den Fonteyne W, El Kissi N, Dufresne A (2012) Simple method for the melt extrusion of a cellulose nanocrystal reinforced hydrophobic polymer. ACS Macro Lett 1(1):236240. https://doi.org/10.1021/mz2001737

11. Brochier Salon MC, Abdelmouleh M, Boufi S, Belgacem MN, Gandini A (2005) Silane adsorption onto cellulose fibers: Hydrolysis and condensation reactions. J Colloid Interf Sci 289(1):249-261. https://doi.org/https://doi.org/10.1016/j.jcis.2005.03.070

12. Calvino C, Macke N, Kato R, Rowan SJ (2020) Development, processing and applications of biosourced cellulose nanocrystal composites. Prog Polym Sci 103:101221.

https://doi.org/10.1016/j.progpolymsci.2020.101221

13. Cao Y, Sakamoto S, Goda K (2007) Effects of heat and alkali treatments on mechanical properties of kenaf fibers. 16th International Conference on Composite Materials: 8-13

14. César NR, de Menezes AJ, Botaro VR (2019) Nanocomposite of cellulose acetate reinforced with nanocrystals modified chemically: Modification with bifunctional reagent. Polym Composite 40:E321-E332. https://doi.org/10.1002/pc.24660

15. Chuayplod P, Aht-Ong D (2018) Mechanochemical-assisted heterogeneous surface modification of parawood microcrystalline cellulose and its effect on the properties of polypropylene composites. World J Eng 15:719-730. https://doi.org/10.1108/WJE-03-2017-0056

16. De Menezes AJ, Siqueira G, Curvelo AAS, Dufresne A (2009) Extrusion and characterization of functionalized cellulose whiskers reinforced polyethylene nanocomposites. Polymer 50:4552-4563. https://doi.org/10.1016/j.polymer.2009.07.038

17. Demir H, Atikler U, Balköse D, Tıhmınlıoğlu F (2006) The effect of fiber surface treatments on the tensile and water sorption properties of polypropylene-luffa fiber composites. Compos Part A- Appl S 37(3):447-456. https://doi.org/10.1016/j.compositesa.2005.05.036

18. Dufresne A (2017) Cellulose nanomaterial reinforced polymer nanocomposites. Curr Opin Colloid In 29:1-8. https://doi.org/10.1016/j.cocis.2017.01.004

19. Espino-Pérez E, Bras J, Almeida G, Plessis C, Belgacem N, Perré P, Domenek S (2018) Designed cellulose nanocrystal surface properties for improving barrier properties in polylactide nanocomposites. Carbohy Polym 183:267-277. https://doi.org/10.1016/j.carbpol.2017.12.005

20. Espino-Pérez E, Bras J, Ducruet V, Guinault A, Dufresne A, Domenek S (2013) Influence of chemical surface modification of cellulose nanowhiskers on thermal, mechanical, and barrier properties of poly (lactide) based bionanocomposites. Eur Polym J 49:3144-3154. https://doi.org/10.1016/j.eurpolymj.2013.07.017

21. Eyley S, Thielemans W (2014) Surface modification of cellulose nanocrystals. Nanoscale 6:77647779. https://doi.org/10.1039/C4NR01756K

22. Fang H, Chen X, Wang S, Cheng S, Ding Y (2019) Enhanced mechanical and oxygen barrier performance in biodegradable polyurethanes by incorporating cellulose nanocrystals with interfacial 
polylactide stereocomplexation. Cellulose 26:9751-9764. https://doi.org/10.1007/s10570-01902742-0

23. Ferreira FV, Trindade GN, Lona LMF, Bernardes JS, Gouveia RF (2019) LDPE-based composites reinforced with surface modified cellulose fibres: 3D morphological and morphometrical analyses to understand the improved mechanical performance. Eur Polym J 117:105-113. https://doi.org/10.1016/j.eurpolymj.2019.05.005

24. Ferrer A, Pal L, Hubbe M (2017) Nanocellulose in packaging: Advances in barrier layer technologies. Ind Crop Pro 95:574-582. https://doi.org/10.1016/j.indcrop.2016.11.012

25. Fortunati E, Peltzer M, Armentano I, Torre L, Jiménez A, Kenny JM (2012) Effects of modified cellulose nanocrystals on the barrier and migration properties of PLA nano-biocomposites. Carbohyd Polym 90:948-956. https://doi.org/10.1016/j.carbpol.2012.06.025

26. Habibi Y (2014) Key advances in the chemical modification of nanocelluloses. Chem Soc Rev 43:1519-1542. https://doi.org/10.1039/C3CS60204D

27. Haque MM, Islam MS, Islam MN (2012) Preparation and characterization of polypropylene composites reinforced with chemically treated coir. J Polym Res 19:9847. https://doi.org/10.1007/s10965-012-9847-z

28. He L, Li W, Chen D, Zhou D, Lu G, Yuan J (2015) Effects of amino silicone oil modification on properties of ramie fiber and ramie fiber/polypropylene composites. Mater Design 77:142-148. https://doi.org/10.1016/j.matdes.2015.03.051

29. Herrera MA, Mathew AP, Oksman K (2017) Barrier and mechanical properties of plasticized and cross-linked nanocellulose coatings for paper packaging applications. Cellulose 24:3969-3980. https://doi.org/10.1007/s10570-017-1405-8

30. Hubbe MA, Ferrer A, Tyagi P, Yin Y, Salas C, Pal L, Rojas OJ (2017) Nanocellulose in thin films, coatings, and plies for packaging applications: A review. BioResources 12:2143-2233

31. Ichimura H, Kurokawa N, Hotta A (2019) Enhancement of the mechanical property of poly ( $\varepsilon$ caprolactone) composites with surface-modified cellulose nanofibers fabricated via electrospinning. MRS Advances 4:385-391. https://doi.org/10.1557/adv.2019.4

32. Inukai S, Kurokawa N, Hotta A (2020) Mechanical properties of poly ( $\varepsilon$-caprolactone) composites with electrospun cellulose nanofibers surface modified by 3-aminopropyltriethoxysilane. J App Poly Sci 137:48599. https://doi.org/10.1002/app.48599

33. Islam MS, Chen L, Sisler J, Tam KC (2018) Cellulose nanocrystal (CNC)-inorganic hybrid systems: synthesis, properties and applications. J Mate Chem B 6:864-883. https://doi.org/10.1039/C7TB03016A

34. Jamaluddin N, Kanno T, Asoh TA, Uyama H (2019) Surface modification of cellulose nanofiber using acid anhydride for poly (lactic acid) reinforcement. Mater Today Comm 21:100587. https://doi.org/10.1016/j.mtcomm.2019.100587

35. Kahavita K, Samarasekara A, Amarasinghe DAS, Karunanayake L (2019) Influence of surface modification of cellulose nanofibers (CNF) as the reinforcement of polypropylene based composite. 
2019 Moratuwa Engineering Research Conference (MERCon): 99-104

36. Kalia S, Thakur K, Celli A, Kiechel MA, Schauer CL (2013) Surface modification of plant fibers using environment friendly methods for their application in polymer composites, textile industry and antimicrobial activities: A review. J Environ Chem Eng 1:97-112.

https://doi.org/10.1016/j.jece.2013.04.009

37. Kargarzadeh H, Mariano M, Gopakumar D, Ahmad I, Thomas S, Dufresne A, Huang J, Lin N (2018) Advances in cellulose nanomaterials. Cellulose 25(4):2151-2189. https://doi.org/10.1007/s10570018-1723-5

38. Kim JT, Netravali AN (2010a) Mechanical, thermal, and interfacial properties of green composites with ramie fiber and soy resins. J Agr Food Chem 58:5400-5407. https://doi.org/10.1021/jf100317y

39. Kim JT, Netravali AN (2010b) Mercerization of sisal fibers: Effect of tension on mechanical properties of sisal fiber and fiber-reinforced composites. Compos Part A- Appl S 41:1245-1252. https://doi.org/10.1016/j.compositesa.2010.05.007

40. Kim JT, Netravali AN (2011) Development of aligned-hemp yarn-reinforced green composites with soy protein resin: Effect of $\mathrm{pH}$ on mechanical and interfacial properties. Compos Sci Technol 71:541-547. https://doi.org/10.1016/j.compscitech.2011.01.004

41. Khan RA, Beck S, Dussault D, Salmieri S, Bouchard J, Lacroix M (2013) Mechanical and barrier properties of nanocrystalline cellulose reinforced poly (caprolactone) composites: Effect of gamma radiation. J Appl Polym Sci 129:3038-3046. https://doi.org/10.1002/app.38896

42. Lai C, Zhang S, Chen X, Sheng L (2014) Nanocomposite films based on TEMPO-mediated oxidized bacterial cellulose and chitosan. Cellulose 21:2757-2772. https://doi.org/10.1007/s10570-0140330-3

43. Lal SS, Mhaske ST (2019) TEMPO-oxidized cellulose nanofiber/kafirin protein thin film crosslinked by Maillard reaction. Cellulose 26:6099-6118. https://doi.org/10.1007/s10570-019-02509-7

44. Larsson PA, Kochumalayil JJ, Wågberg L (2013) Oxygen and water vapour barrier films with low moisture sensitivity fabricated from self-cross-linking fibrillated cellulose. 15th Fundamental Research Symposium: Advances in Pulp and Paper Research: 851-866

45. Le Gars M, Bras J, Salmi-Mani H, Ji M, Dragoe D, Faraj H, Domenek S, Belgacem N, Roger P (2020) Polymerization of glycidyl methacrylate from the surface of cellulose nanocrystals for the elaboration of PLA-based nanocomposites. Carbohyd Polym 234:115899. https://doi.org/10.1016/j.carbpol.2020.115899

46. Lee H, Sundaram J, Mani S (2017) Production of cellulose nanofibrils and their application to food: a review. In Nanotechnology (pp. 1-33). Springer

47. Lepetit A, Drolet R, Tolnai B, Montplaisir D, Lucas R, Zerrouki R (2017a) Microfibrillated cellulose with sizing for reinforcing composites with LDPE. Cellulose 24:4303-4312. https://doi.org/10.1007/s10570-017-1429-0

48. Lepetit A, Drolet R, Tolnai B, Montplaisir D, Zerrouki R (2017b) Alkylation of microfibrillated celluloseA green and efficient method for use in fiber-reinforced composites. Polymer 126:48-55. 
https://doi.org/10.1016/j.polymer.2017.08.024

49. Li MC, Mei C, Xu X, Lee S, Wu Q (2016) Cationic surface modification of cellulose nanocrystals: Toward tailoring dispersion and interface in carboxymethyl cellulose films. Polymer 107:200-210. https://doi.org/10.1016/j.polymer.2016.11.022

50. Li W, Wang S, Wang W, Qin C, Wu M (2019) Facile preparation of reactive hydrophobic cellulose nanofibril film for reducing water vapor permeability (WVP) in packaging applications. Cellulose 26:3271-3284. https://doi.org/10.1007/s10570-019-02270-x

51. Liu S, Chen Y, Liu C, Gan L, Ma X, Huang J (2019) Polydopamine-coated cellulose nanocrystals as an active ingredient in poly (vinyl alcohol) films towards intensifying packaging application potential. Cellulose 26:9599-9612. https://doi.org/10.1007/s10570-019-02749-7

52. Lopattananon N, Jitkalong D, Seadan M (2011) Hybridized reinforcement of natural rubber with silane-modified short cellulose fibers and silica. J Appl Polym Sci 120(6):3242-3254. https://doi.org/10.1002/app.33374

53. Lu P, Guo M, Xu Z, Wu M (2018) Application of nanofibrillated cellulose on BOPP/LDPE film as oxygen barrier and antimicrobial coating based on cold plasma treatment. Coatings 8:207. https://doi.org/10.3390/coatings8060207

54. Ma Y, Qian S, Hu L, Qian J, Fontanillo Lopez CA, Xu L (2019) Mechanical, thermal, and morphological properties of PLA biocomposites toughened with silylated bamboo cellulose nanowhiskers. Polym Composites 40:3012-3019. https://doi.org/10.1002/pc.25144

55. Martínez-Sanz M, Abdelwahab MA, Lopez-Rubio A, Lagaron JM, Chiellini E, Williams TG, Wood DF, Orts WJ, Imam SH (2013) Incorporation of poly (glycidylmethacrylate) grafted bacterial cellulose nanowhiskers in poly (lactic acid) nanocomposites: Improved barrier and mechanical properties. Eur Polym J 49:2062-2072. https://doi.org/10.1016/j.eurpolymj.2013.04.035

56. Meriçer Ç, Minelli M, De Angelis MG, Baschetti MG, Stancampiano A, Laurita R, Gherardi M, Colombo V, Trifol J, Szabo P (2016) Atmospheric plasma assisted PLA/microfibrillated cellulose (MFC) multilayer biocomposite for sustainable barrier application. Ind Crop Prod 93:235-243. https://doi.org/10.1016/j.indcrop.2016.03.020

57. Mishra S, Misra M, Tripathy SS, Nayak SK, Mohanty AK (2001) Potentiality of pineapple leaf fibre as reinforcement in PALF-polyester composite: Surface modification and mechanical performance. J Reinf Plast Comp 20(4):321-334. https://doi.org/10.1177/073168401772678779

58. Mohit H, Arul Mozhi Selvan V (2018) A comprehensive review on surface modification, structure interface and bonding mechanism of plant cellulose fiber reinforced polymer based composites. Compos Interfaces 25(5-7):629-667. https:// doi.org/10.1080/09276440.2018.1444832

59. Penjumras P, AbdulRahman R, Talib RA, Abdan K (2016) Effect of silane coupling agent on properties of biocomposites based on poly (lactic acid) and durian rind cellulose. IOP Conference Series: Materials Science and Engineering

60. Pereira ALS, Nascimento DMdo SFilhoM, sáM, Morais JPS, Vasconcelos NF, Feitosa JPA, Brígida AIS, Rosa MdeF (2014) Improvement of polyvinyl alcohol properties by adding nanocrystalline cellulose 
isolated from banana pseudostems. Carbohyd Polym 112:165-172.

https://doi.org/10.1016/j.carbpol.2014.05.090

61. Pereira PHF, Rosa MdeF, Cioffi MOH, Benini KCCdeC, Milanese AC, Voorwald HJC, Mulinari DR (2015) Vegetal fibers in polymeric composites: a review. Polímeros 25:9-22. https://doi.org/10.1590/01041428.1722

62. Pinheiro IF, Ferreira FV, Souza DHS, Gouveia RF, Lona LMF, Morales AR, Mei LHI (2017) Mechanical, rheological and degradation properties of PBAT nanocomposites reinforced by functionalized cellulose nanocrystals. Eur Polym J 97:356-365. https://doi.org/10.1016/j.eurpolymj.2017.10.026

63. Plappert SF, Quraishi S, Pircher N, Mikkonen KS, Veigel S, Klinger KM, Potthast A, Rosenau T, Liebner FW (2018) Transparent, flexible, and strong 2, 3-dialdehyde cellulose films with high oxygen barrier properties. Biomacromol 19:2969-2978. https://doi.org/10.1021/acs.biomac.8b00536

64. Qasim U, Osman Al, Al-Muhtaseb AH, Farrell C, Al-Abri M, Ali M, Vo DVN, Jamil F, Rooney DW (2020) Renewable cellulosic nanocomposites for food packaging to avoid fossil fuel plastic pollution: a review. Environ Chem Lett. https://doi.org/10.1007/s10311-020-01090-x

65. Ragoubi M, Bienaimé D, Molina S, George B, Merlin A (2010) Impact of corona treated hemp fibres onto mechanical properties of polypropylene composites made thereof. Ind Crop Prod 31:344-349. https://doi.org/10.1016/j.indcrop.2009.12.004

66. Ragoubi M, George B, Molina S, Bienaimé D, Merlin A, Hive JM, Dahoun A (2012) Effect of corona discharge treatment on mechanical and thermal properties of composites based on miscanthus fibres and polylactic acid or polypropylene matrix. Compos Part A- Appl S 43:675-685. https://doi.org/10.1016/j.compositesa.2011.12.025

67. Rodionova G, Saito T, Lenes M, Eriksen $\emptyset$, Gregersen $\emptyset$, Fukuzumi H, Isogai A (2012) Mechanical and oxygen barrier properties of films prepared from fibrillated dispersions of TEMPO-oxidized Norway spruce and Eucalyptus pulps. Cellulose 19:705-711. https://doi.org/10.1007/s10570-012-9664-x

68. Rout J, Tripathy SS, Misra M, Mohanty AK, Nayak SK (2001) The influence of fiber surface modification on the mechanical properties of coir-polyester composites. Polym Composite 22:468476. https://doi.org/10.1002/pc.10552

69. Saallah S, Misson M, Siddiquee S, Roslan J, Naim MN, Bakar NFA, Lenggoro IW (2020) Nanocellulose and Nanocellulose-Based Composites for Food Applications. In Composite Materials: Applications in Engineering, Biomedicine and Food Science (pp. 369-385) Springer

70. Saedi S, Madaeni SS, Seidi F, Shamsabadi AA, Laki S (2014) Fixed facilitated transport of $\mathrm{CO}_{2}$ through integrally-skinned asymmetric polyethersulfone membrane using a novel synthesized Poly (acrylonitrile-co-N, N-Dimethylaminopropyl acrylamide). Chem Eng J 236:263-273. https://doi.org/10.1016/j.cej.2013.09.092

71. Sain MM, Kokta BV, Maldas D (1993) Effect of reactive additives on the performance of cellulose fiber-filled polypropylene composites. J Adhes Sci Technol 7:49-61.

https://doi.org/10.1163/156856193X00196

Page 20/30 
72. Saito T, Isogai A (2006) Introduction of aldehyde groups on surfaces of native cellulose fibers by TEMPO-mediated oxidation. Colloid Surfaces A 289:219-225.

https://doi.org/10.1016/j.colsurfa.2006.04.038

73. Sarikanat M, Seki Y, Sever K, Bozaci E, Demir A, Ozdogan E (2016) The effect of argon and air plasma treatment of flax fiber on mechanical properties of reinforced polyester composite. $\mathrm{J}$ Ind Text 45:1252-1267. https://doi.org/10.1177/1528083714557057

74. Sato A, Yoshimura T, Kabusaki D, Okumura H, Homma Y, Nakatsubo F, Yano H (2019) Multifunctional effect of alkenyl-succinic-anhydride-modified microfibrillated celluloses as reinforcement and a dispersant of $\mathrm{CaCO}_{3}$ in high-density polyethylene. Cellulose 26:6641-6651. https://doi.org/10.1007/s10570-019-02544-4

75. Sehaqui $H$, Zimmermann T, Tingaut $P$ (2014) Hydrophobic cellulose nanopaper through a mild esterification procedure. Cellulose 21:367-382. https://doi.org/10.1007/s10570-013-0110-5

76. Selulosa-Polivinilklorida SRN, Sheltami RM, Kargarzadeh H, Abdullah I (2015) Effects of silane surface treatment of cellulose nanocrystals on the tensile properties of cellulose-polyvinyl chloride nanocomposite. Sains Malays 44(6):801-810. https://doi.org/10.17576/jsm-2015-4406-05

77. Seo YR, Kim JW, Hoon S, Kim J, Chung JH, Lim KT (2018) Cellulose-based nanocrystals: Sources and applications via agricultural byproducts. J Biosyst Eng 43(1):59-71. https://doi.org/10.5307/JBE.2018.43.1.059

78. Sharma S, Zhang X, Nair SS, Ragauskas A, Zhu J, Deng Y (2014) Thermally enhanced high performance cellulose nano fibril barrier membranes. RSC Advances 4:45136-45142. https://doi.org/10.1039/C4RA07469F

79. Shojaeiarani J, Bajwa DS, Hartman K (2019) Esterified cellulose nanocrystals as reinforcement in poly (lactic acid) nanocomposites. Cellulose 26:2349-2362. https://doi.org/10.1007/s10570-01802237-4

80. Sirviö JA, Kolehmainen A, Visanko M, Liimatainen H, Niinimäki J, Hormi OEO (2014) Strong, selfstanding oxygen barrier films from nanocelluloses modified with regioselective oxidative treatments. ACS Appl Mater Inter 6:14384-14390. https://doi.org/10.1021/am503659j

81. Somord K, Somord K, Suwantong O, Thanomsilp C, Peijs T, Soykeabkaew N (2018) Self-reinforced poly (lactic acid) nanocomposites with integrated bacterial cellulose and its surface modification. Nanocomposites 4:102-111. https://doi.org/10.1080/20550324.2018.1532671

82. Song Z, Xiao H, Zhao Y (2014) Hydrophobic-modified nano-cellulose fiber/PLA biodegradable composites for lowering water vapor transmission rate (WVTR) of paper. Carbohyd Polym 111:442448. https://doi.org/10.1016/j.carbpol.2014.04.049

83. Sreekumar PA, Thomas SP, marc Saiter J, Joseph K, Unnikrishnan G, Thomas S (2009) Effect of fiber surface modification on the mechanical and water absorption characteristics of sisal/polyester composites fabricated by resin transfer molding. Compos Part A- Appl S 40:1777-1784. https://doi.org/10.1016/j.compositesa.2009.08.013 
84. Thakur MK, Gupta RK, Thakur VK (2014) Surface modification of cellulose using silane coupling agent. Carbohyd Polymer 111:849-855. https://doi.org/10.1016/j.carbpol.2014.05.041

85. Threepopnatkul P, Kaerkitcha N, Athipongarporn N (2009) Effect of surface treatment on performance of pineapple leaf fiber-polycarbonate composites. Composites Part B- Eng 40:628632. https://doi.org/10.1016/j.compositesb.2009.04.008

86. Tomé LC, Brandao L, Mendes AM, Silvestre AJD, Neto CP, Gandini A, Freire CSR, Marrucho IM (2010) Preparation and characterization of bacterial cellulose membranes with tailored surface and barrier properties. Cellulose 17:1203-1211. https://doi.org/10.1007/s10570-010-9457-z

87. Trache D, Hussin MH, Chuin CTH, Sabar S, Fazita MRN, Taiwo OFA, Hassan TM, Haafiz MKM (2016) Microcrystalline cellulose: Isolation, characterization and bio-composites application - A review. Int J Biol Macromol 93:789-804. https://doi.org/10.1016/j.ijbiomac.2016.09.056

88. Vilarinho F, Sanches Silva A, Vaz MF, Farinha JP (2018) Nanocellulose in green food packaging. Crit Rev Food Sci 58:1526-1537. https://doi.org/10.1080/10408398.2016.1270254

89. Virtanen S, Vuoti S, Heikkinen H, Lahtinen P (2014) High strength modified nanofibrillated cellulosepolyvinyl alcohol films. Cellulose 21:3561-3571. https://doi.org/10.1007/s10570-014-0347-7

90. Visanko M, Liimatainen H, Sirviö JA, Mikkonen KS, Tenkanen M, Sliz R, Hormi O, Niinimäki J (2015) Butylamino-functionalized cellulose nanocrystal films: barrier properties and mechanical strength. RSC Advances 5(20):15140-15146. https://doi.org/10.1039/C4RA15445B

91. Wang J, Gardner DJ, Stark NM, Bousfield DW, Tajvidi M, Cai Z (2018) Moisture and oxygen barrier properties of cellulose nanomaterial-based films. ACS Sustain Chem Eng 6(1):49-70. https://doi.org/10.1021/acssuschemeng.7b03523

92. Wang L, Chen C, Wang J, Gardner DJ, Tajvidi M (2020) Cellulose nanofibrils versus cellulose nanocrystals: Comparison of performance in flexible multilayer films for packaging applications. Food Packag Shelf Life 23:100464. https://doi.org/10.1016/j.fpsl.2020.100464

93. Xia J, Zhang Z, Liu W, Li VCF, Cao Y, Zhang W, Deng Y (2018) Highly transparent $100 \%$ cellulose nanofibril films with extremely high oxygen barriers in high relative humidity. Cellulose 25:40574066. https://doi.org/10.1007/s10570-018-1843-y

94. Xu K, Li K, Tu D, Zhong T, Xie C (2014) Reinforcement on the mechanical, thermal, and waterresistance properties of the wood flour/chitosan/poly(vinyl chloride) composites by physical and chemical modification. J App Polym Sci 131:1-7. https://doi.org/10.1002/app.40757

95. Yano H, Omura H, Honma Y, Okumura H, Sano H, Nakatsubo F (2018) Designing cellulose nanofiber surface for high density polyethylene reinforcement. Cellulose 25:3351-3362. https://doi.org/10.1007/s10570-018-1787-2

96. Yin Y, Zhao L, Jiang X, Wang H, Gao W (2017) Poly (lactic acid)-based biocomposites reinforced with modified cellulose nanocrystals. Cellulose 24:4773-4784. https://doi.org/10.1007/s10570-017$1455-\mathrm{y}$

97. Yu H, Yan C, Yao J (2014) Fully biodegradable food packaging materials based on functionalized cellulose nanocrystals/poly (3-hydroxybutyrate-co-3-hydroxyvalerate) nanocomposites. Rsc 
Advances 4:59792-59802. https://doi.org/10.1039/C4RA12691B

98. Zaman HU, Khan MA, Khan RA (2009) Improvement of mechanical properties of jute fiberspolyethylene/polypropylene composites: Effect of green dye and UV radiation. Polym-Plast Technol 48:1130-1138. https://doi.org/10.1080/03602550903147262

99. Zaman HU, Khan MA, Khan RA, Mollah MZI, Pervin S, Al-Mamun MD (2010) A comparative study between gamma and UV radiation of jute fabrics/polypropylene composites: Effect of starch. J Reinf Plast Comp 29:1930-1939. https://doi.org/10.1177/0731684409343325

100. Zhang Z, Cai S, Li Y, Wang Z, Long Y, Yu T, Shen Y (2020) High performances of plant fiber reinforced Composites - A new insight from hierarchical microstructures. Compos Sci Technol 194:108151. https://doi.org/10.1016/j.compscitech.2020.108151

\section{Tables}

Table 1. Effect of modification of cellulose fibers for decreasing the water vapor and oxygen permeability and water uptake of composites 


\begin{tabular}{|c|c|c|c|c|c|c|}
\hline Matrix & Filler & Modification & OP/OTR & WVP/WVTR & $\begin{array}{c}\text { Water } \\
\text { uptake } \\
(\%)\end{array}$ & Reference \\
\hline \multirow{2}{*}{$\begin{array}{l}\text { Bacterial } \\
\text { cellulose }\end{array}$} & \multirow[t]{2}{*}{-} & Untreated & $10.2 \mathrm{a}$ & $1.10 \mathrm{~b}$ & - & \multirow{2}{*}{$\begin{array}{l}\text { (Tomé et } \\
\text { al. 2010) }\end{array}$} \\
\hline & & Hexanoyl chloride & $4.3 \mathrm{a}$ & $0.58 \mathrm{~b}$ & - & \\
\hline \multirow[t]{2}{*}{ Polylactic acid } & \multirow{2}{*}{$\begin{array}{c}\text { Cellulose } \\
\text { nanowhiskers }\end{array}$} & Untreated & $0.57 \pm 0.09 a$ & $6.51 \pm 0.42 \mathrm{~b}$ & - & \multirow{2}{*}{$\begin{array}{l}\text { (Espino- } \\
\text { Pérez et al. } \\
2013 \text { ) }\end{array}$} \\
\hline & & n-Octadecyl-isocyanate & $0.44 \pm 0.17 a$ & $2.30 \pm 0.01 b$ & - & \\
\hline \multirow[t]{2}{*}{ Nanocellulose } & \multirow[t]{2}{*}{-} & Untreated & $2.62 \times 10^{-3} \mathrm{a}$ & $215 c$ & - & \multirow{2}{*}{$\begin{array}{l}\text { (Herrera et } \\
\text { al. 2017) }\end{array}$} \\
\hline & & Citric acid & $1.7 \times 10^{-3} \mathrm{a}$ & $210 c$ & - & \\
\hline \multirow[t]{5}{*}{ Polylactic acid } & \multirow[t]{5}{*}{ Cellulose nanocrystal } & Untreated & $2.77 \pm 0.26 \times 10^{-1} \mathrm{a}$ & $3.0 \pm 0.5 b$ & - & \multirow{3}{*}{$\begin{array}{l}\text { (Espino- } \\
\text { Pérez et al. } \\
2018 \text { ) }\end{array}$} \\
\hline & & Phenylacetic acid & $2.13 \pm 0.26 \times 10^{-1} \mathrm{a}$ & $1.8 \pm 0.2 \mathrm{~b}$ & - & \\
\hline & & Hydrocinnamic acid & $2.53 \pm 0.26 \times 10^{-1} \mathrm{a}$ & $1.8 \pm 0.2 \mathrm{~b}$ & - & \\
\hline & & Untreated & $27.8 \pm 0.1 \mathrm{~d}$ & $1.05 \pm 0.02 \mathrm{~b}$ & - & \multirow{2}{*}{$\begin{array}{l}\text { (Fortunati } \\
\text { et al. 2012) }\end{array}$} \\
\hline & & Beycostat A B09 & $22.7 \pm 1.1 \mathrm{~d}$ & $0.69 \pm 0.01 \mathrm{~b}$ & - & \\
\hline \multirow[t]{2}{*}{ Polycaprolactone } & \multirow[t]{2}{*}{ Cellulose nanocrystal } & Untreated & $146 \mathrm{e}$ & - & - & \multirow{2}{*}{$\begin{array}{l}\text { (Khan et al. } \\
\text { 2013) }\end{array}$} \\
\hline & & $\gamma$-irra diation & $118 \mathrm{e}$ & - & - & \\
\hline \multirow{12}{*}{$\begin{array}{l}\text { Cellulose } \\
\text { nanofiber }\end{array}$} & \multirow[t]{12}{*}{-} & Untreated & - & - & 17 & \multirow{2}{*}{$\begin{array}{l}\text { (Sehaqui } \\
\text { et al. 2014) }\end{array}$} \\
\hline & & Esterification & - & - & 12 & \\
\hline & & Untreated & $2.62 \times 10^{-4} \mathrm{a}$ & $64.8 \mathrm{~b}$ & - & \multirow{2}{*}{$\begin{array}{l}\text { (Sharma et } \\
\text { al. 2014) }\end{array}$} \\
\hline & & Heat & $1.54 \times 10^{-5} \mathrm{a}$ & $31.8 \mathrm{~b}$ & - & \\
\hline & & Untreated & $2.31 \times 10^{-3} \mathrm{a}$ & - & - & \multirow{2}{*}{$\begin{array}{l}\text { (Xia et al. } \\
2018 \text { ) }\end{array}$} \\
\hline & & Heat & $8.95 \times 10^{-4} a$ & - & - & \\
\hline & & Untreated & $1.4 \times 10^{-2} \mathrm{a}$ & $9.26 \mathrm{~b}$ & 22 & \multirow{2}{*}{$\begin{array}{l}\text { (Larsson et } \\
\text { al. 2013) }\end{array}$} \\
\hline & & Periodate & $3.39 \times 10^{-3} \mathrm{a}$ & $4.4 \mathrm{~b}$ & 15 & \\
\hline & & Untreated & - & $9.0 \times 10^{2} \mathrm{~b}$ & - & \multirow{2}{*}{$\begin{array}{l}\text { (Li et al. } \\
\text { 2019) }\end{array}$} \\
\hline & & $\begin{array}{l}\text { 10-undecylenoyl } \\
\text { chloride }\end{array}$ & - & $3.2 \times 10^{2} \mathrm{~b}$ & - & \\
\hline & & Untreated & $1.55 \mathrm{~d}$ & - & - & \multirow{2}{*}{$\begin{array}{l}\text { (Rodionova } \\
\text { et al. 2012) }\end{array}$} \\
\hline & & $\begin{array}{l}\text { Tempo-mediated } \\
\text { oxidation }\end{array}$ & $5.6 \times 10^{-2} \mathrm{~d}$ & - & - & \\
\hline \multirow[t]{6}{*}{ Polylactic acid } & Bacterial cellulose & Untreated & $2.17 \pm 0.02 \times 10^{-1} \mathrm{a}$ & $1.46 \pm 0.05 b$ & - & (Ambrosio- \\
\hline & & Lactic acid oligomers & $1.75 \pm 0.02 \times 10^{-1} \mathrm{a}$ & $1.28 \pm 0.01 \mathrm{~b}$ & - & $\begin{array}{l}\text { Martín et } \\
\text { al. 2015) }\end{array}$ \\
\hline & & Untreated & $2.48 \pm 0.03 \times 10^{-1} \mathrm{a}$ & - & - & (Martínez- \\
\hline & & $\begin{array}{l}\text { Poly(glycidyl } \\
\text { methacrylate) }\end{array}$ & $2.07 \pm 0.02 \times 10^{-1} \mathrm{a}$ & - & - & $\begin{array}{l}\text { Sanz et al. } \\
\text { 2013) }\end{array}$ \\
\hline & Bacterial & Untreated & - & $130 \mathrm{c}$ & - & (Somord et \\
\hline & cellulose & Silane & - & $75 \mathrm{c}$ & - & al. 2018) \\
\hline Low density & Microfibrillated & Untreated & - & - & 2 & (Lepetit et \\
\hline polyethylene & cellulose & Propargyl bromide & - & - & 1.1 & al. 2017b) \\
\hline & & Allyl bromide & - & - & 1.7 & \\
\hline & & Propyl bromide & - & - & 2 & \\
\hline & & $\begin{array}{l}\text { (2-dodecen-1-yl) } \\
\text { succinic anhydride }\end{array}$ & - & - & 0.3 & \\
\hline Polypropylene & Coir & Untreated & - & - & 0.45 & (Haque et \\
\hline & & $\begin{array}{l}\mathrm{NaIO}_{4} \text { and } \mathrm{p}- \\
\text { aminophenol }\end{array}$ & - & - & 0.25 & al. 2012) \\
\hline & Carboxymethyl & Untreated & - & - & 1.3 & (Chuayplod \\
\hline & cellulose & Benzoyl chloride & - & - & 0.4 & $\begin{array}{l}\text { \& Aht-Ong } \\
\text { 2018) }\end{array}$ \\
\hline
\end{tabular}

Page 24/30 


\begin{tabular}{|l|l|l|l|l|l|l|} 
& Cellulose nanofiber & Untreated & - & - & 0.24 & (Kahavita \\
\cline { 3 - 5 } & & Si69 & - & - & 0.16 & et al. 2019) \\
\hline
\end{tabular}

\begin{tabular}{ll} 
OP & oxygen permeability \\
\hline OTR & oxygen transmission rate \\
\hline WVP & water vapor permeability \\
\hline WVTR & water vapor transmission rate \\
\hline a & $\times 10^{-10} \cdot \mathrm{cm}^{3} \cdot \mathrm{cm} \cdot \mathrm{cm}^{-2} \cdot \mathrm{s}^{-1} \cdot \mathrm{cmHg}^{-1}$ \\
\hline $\mathrm{b}$ & $\times 10^{-14} \cdot \mathrm{kg} \cdot \mathrm{m} \cdot \mathrm{s}^{-1} \cdot \mathrm{m}^{-2} \cdot \mathrm{Pa}^{-1}$ \\
\hline $\mathrm{c}$ & $\mathrm{g} \cdot \mathrm{day}^{-1} \cdot \mathrm{m}^{-2}$ \\
\hline $\mathrm{d}$ & $\mathrm{cm}^{3} \cdot \mathrm{mm} \cdot \mathrm{m}^{-2} \cdot \mathrm{day}^{-1}$ \\
\hline $\mathrm{e}$ & $\mathrm{mL} \cdot \mathrm{m}^{-2} \cdot \mathrm{day}^{-1}$
\end{tabular}

Table 2. Effect of chemical modification of cellulose fibers on the mechanical strength of composites 


\begin{tabular}{|c|c|c|c|c|c|c|}
\hline Polymer & $\begin{array}{c}\text { Reinforcing } \\
\text { material }\end{array}$ & Modifier & $\begin{array}{c}\mathrm{TS} \\
(\mathrm{MPa})\end{array}$ & $\begin{array}{l}\text { Modulus } \\
\text { (GPa) }\end{array}$ & $\begin{array}{c}\text { Elongation } \\
\text { at break } \\
\text { (\%) }\end{array}$ & Reference \\
\hline \multirow[t]{2}{*}{ Cellulose acetate } & \multirow{2}{*}{$\begin{array}{c}\text { Cellulose } \\
\text { nanocrystals }\end{array}$} & Untreated & $50.1 \pm 21.5$ & $0.48 \pm 0.19$ & $2.2 \pm 0.8$ & \multirow{2}{*}{$\begin{array}{l}\text { (César et al. } \\
\text { 2019) }\end{array}$} \\
\hline & & BTDA & $118.9 \pm 10.4$ & $1.19 \pm 0.35$ & $2.8 \pm 0.3$ & \\
\hline \multirow{3}{*}{$\begin{array}{l}\text { Carboxymethyl } \\
\text { cellulose }\end{array}$} & \multirow{3}{*}{$\begin{array}{c}\text { Cellulose } \\
\text { nanocrystals }\end{array}$} & Untreated & 52 & 0.38 & 41 & \multirow[t]{3}{*}{ (Li et al. 2016) } \\
\hline & & EPTMAC & 54 & 0.6 & 37 & \\
\hline & & Dihexyl-OH & $23.7 \pm 1.2$ & $0.30 \pm 0.02$ & $267 \pm 10$ & \\
\hline \multirow{9}{*}{$\begin{array}{l}\text { High density } \\
\text { polyethylene }\end{array}$} & \multirow[t]{7}{*}{ Cellulose nanofiber } & Untreated & $34.2 \pm 0.10$ & $2.08 \pm 0.41$ & & \multirow{7}{*}{$\begin{array}{l}\text { (Yano et al. } \\
\text { 2018) }\end{array}$} \\
\hline & & $\mathrm{Ac}$ & $39.6 \pm 0.42$ & $2.25 \pm 0.10$ & & \\
\hline & & Myr & $50.4 \pm 0.80$ & $2.60 \pm 0.02$ & & \\
\hline & & Ste & $48.1 \pm 0.44$ & $2.42 \pm 0.11$ & & \\
\hline & & Cyc & $47.2 \pm 0.22$ & $2.78 \pm 0.11$ & & \\
\hline & & $\mathrm{Piv}$ & $51.2 \pm 0.89$ & $3.32 \pm 0.04$ & & \\
\hline & & $\mathrm{t}-\mathrm{BuC}$ & $48.2 \pm 0.06$ & $2.96 \pm 0.04$ & & \\
\hline & \multirow[t]{2}{*}{ Cellulose nanofiber } & Untreated & $25.2 \pm 0.49$ & $1.26 \pm 0.03$ & $>10$ & \multirow{2}{*}{$\begin{array}{l}\text { (Sato et al. } \\
\text { 2019) }\end{array}$} \\
\hline & & PP-g-MA & $40.7 \pm 2.45$ & $1.89 \pm 0.12$ & 4.3 & \\
\hline \multirow{8}{*}{$\begin{array}{l}\text { Low density } \\
\text { polyethylene }\end{array}$} & \multirow{2}{*}{$\begin{array}{l}\text { Microfibrillated } \\
\text { cellulose }\end{array}$} & Untreated & 26.5 & 0.28 & & \multirow{2}{*}{$\begin{array}{l}\text { (Lepetit et al. } \\
\text { 2017b) }\end{array}$} \\
\hline & & $\begin{array}{l}\text { Propargyl } \\
\text { bromide }\end{array}$ & 32.5 & 0.33 & & \\
\hline & \multirow[t]{4}{*}{ Cellulose nanofiber } & Untreated & 10 & 0.05 & 39 & \multirow{2}{*}{$\begin{array}{l}\text { (Ferreira et } \\
\text { al. 2019) }\end{array}$} \\
\hline & & HDMS & 16 & 0.07 & 28 & \\
\hline & & Untreated & 26.5 & 0.26 & & \multirow{2}{*}{$\begin{array}{l}\text { (Lepetit et al. } \\
\text { 2017a) }\end{array}$} \\
\hline & & $\begin{array}{l}\text { (2-dodecen-1-yl) } \\
\text { succinic } \\
\text { anhydride }\end{array}$ & 31.5 & 0.35 & & \\
\hline & \multirow[t]{2}{*}{ Cellulose nanofiber } & Untreated & 12 & 0.35 & 80 & \multirow{2}{*}{$\begin{array}{l}\text { (Ahmadi et al. } \\
\text { 2017) }\end{array}$} \\
\hline & & PMMA & 14 & 0.48 & 100 & \\
\hline \multirow{4}{*}{$\begin{array}{c}\text { Linear low density } \\
\text { polyethylene }\end{array}$} & \multirow{2}{*}{$\begin{array}{c}\text { Cellulose } \\
\text { nanocrystals }\end{array}$} & Untreated & $21.5 \pm 0.27$ & $0.51 \pm 0.08$ & $54.9 \pm 8.9$ & \multirow{2}{*}{$\begin{array}{l}\text { (Anžlovar et } \\
\text { al. 2018) }\end{array}$} \\
\hline & & $\mathrm{AC}$ & $21.3 \pm 0.41$ & $0.51 \pm 0.08$ & $33.7 \pm 6.1$ & \\
\hline & \multirow[t]{2}{*}{ Cellulose fiber } & Untreated & 16 & & 700 & (Lopattananon \\
\hline & & Si69 & 22 & & 650 & et al. 2011) \\
\hline Polycaprolactone & Cellulose nanofiber & Untreated & & 0.41 & & (Ichimura et \\
\hline & & PCL & & 0.49 & & al. 2019) \\
\hline & & Untreated & $32.2 \pm 1.8$ & $0.698 \pm 0.033$ & $9.9 \pm 0.4$ & (Inukai et al. \\
\hline & & APS & $32.8 \pm 0.6$ & $0.744 \pm 0.018$ & $9.0 \pm 0.3$ & 2020) \\
\hline & Cellulose & Untreated & $40 \pm 1$ & & $5.3 \pm 0.6$ & (Espino-Pérez \\
\hline & nanowhiskers & $\begin{array}{l}\text { Poly(n-octa decyl- } \\
\text { isocyanate) }\end{array}$ & $51 \pm 2$ & & $5.6 \pm 1.2$ & et al.2013) \\
\hline & & Untreated & $47.04 \pm 2.02$ & $4.84 \pm 0.43$ & $2.58 \pm 0.40$ & (Penjumras et \\
\hline & & APTES & $55.37 \pm 0.94$ & $6.40 \pm 0.22$ & $2.44 \pm 0.19$ & al. 2016) \\
\hline & & Untreated & $49.98 \pm 1.80$ & & $1.90 \pm 0.4$ & (Yin et al. \\
\hline & & TCT-HA & $48.28 \pm 0.90$ & & $3.10 \pm 0.5$ & 2017) \\
\hline & & Untreated & $55.36 \pm 4.21$ & $3.37 \pm 0.29$ & $2.23 \pm 0.31$ & (Shojaeiarani \\
\hline & & Valeric acid & $68.77 \pm 0.88$ & $4.85 \pm 0.28$ & $5.01 \pm 0.29$ & et al. 2019) \\
\hline & Bacterial cellulose & Untreated & 19 & 0.41 & 30 & (Ma et al. \\
\hline & nanowhiskers & A-1100 & 23 & 0.34 & 110 & 2019) \\
\hline & & A-189 & 9 & 0.13 & 205 & \\
\hline & Cellulose nanofiber & Untreated & $16.7 \pm 2.4$ & & $2.2 \pm 0.8$ & (Jamaluddin et \\
\hline & & Acetylation & $20.9 \pm 4.1$ & & $2.5 \pm 0.5$ & al. 2019) \\
\hline Polypropylene & Cellulose nanofiber & Untreated & 22 & & 12.5 & (Kahavita et \\
\hline
\end{tabular}




\section{Figures}

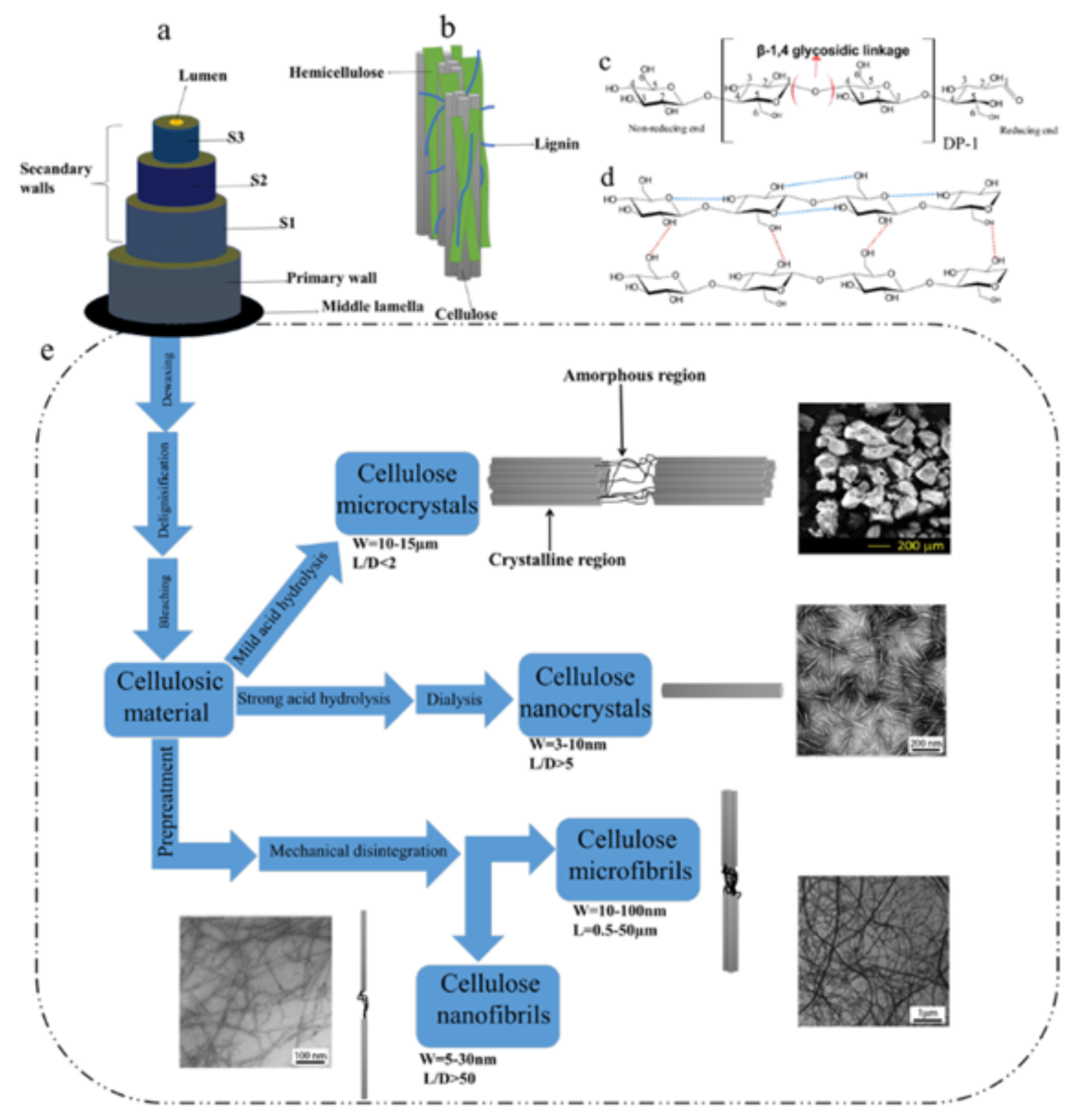

Figure 1

(a) Hierarchical microstructures of elementary fibers, adapted from (Pereira et al. 2015), (b) cellulose fibrils embedded in hemicellulose and lignin matrix, adapted from (Lee et al. 2017), (c) chemical structure of cellulose, (d) inter- and intra-molecular hydrogen bonding, adapted from (Islam et al. 2018), and (e) production of cellulosic reinforcing materials from plant fibers (Kargarzadeh et al. 2018; Trache et al. 2016). SEM images are reprinted with permission from (Abu-Thabit et al. 2020; Calvino et al. 2020; Lee et al. 2017). 

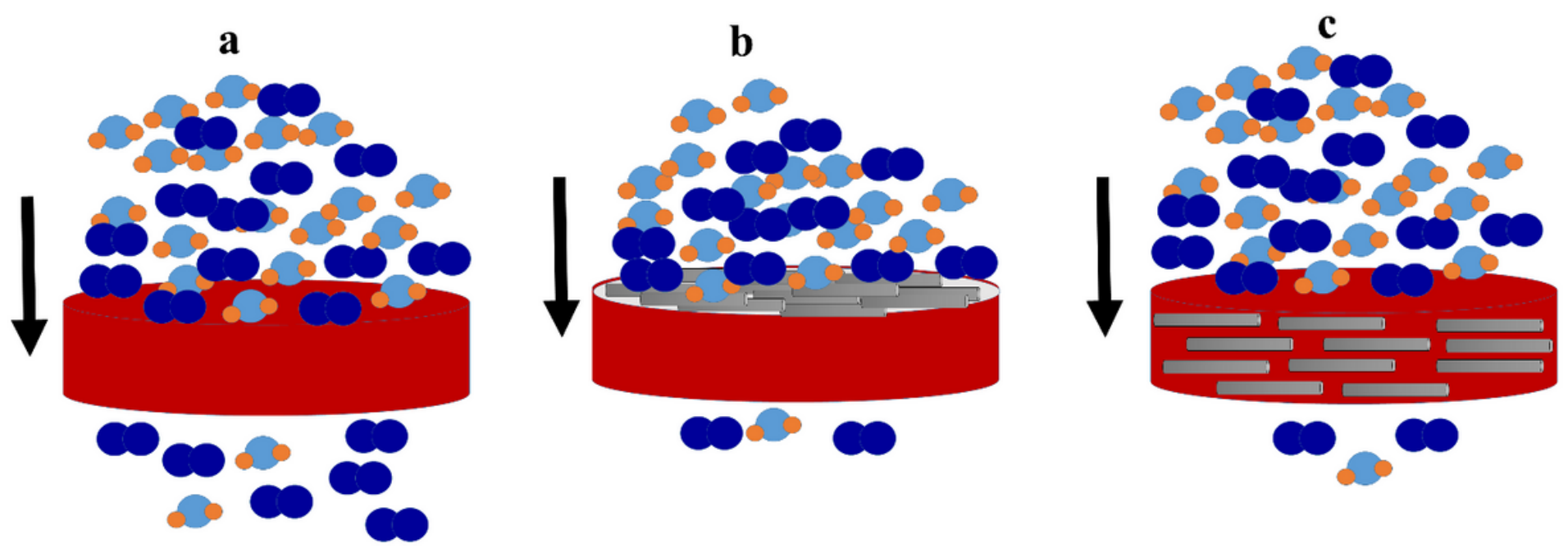

Oxygen

Water

$\mathrm{CNC}$

Film

Figure 2

Schematic representation of (a) permeation of oxygen through a polymer layer, (b) a bilayer of polymer and cellulose nanocrystals (CNC), and (c) a composite of polymer and CNC. 


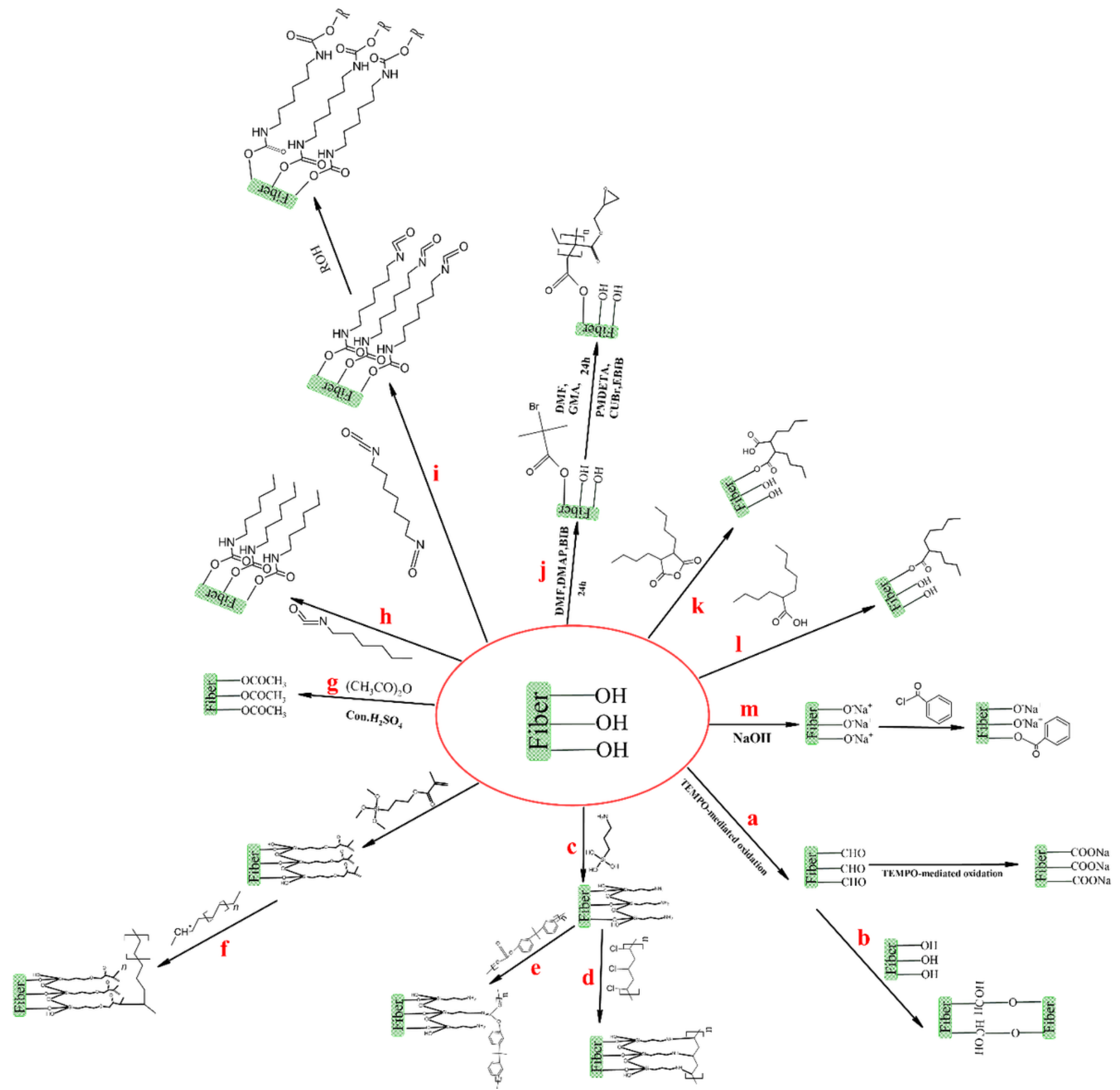

Figure 3

(a) TEMPO-mediated oxidation of fibers (Eyley \& Thielemans 2014), (b) reinforcement of cellulose fibers through TEMPO-mediated oxidation (Saito \& Isogai 2006), (c) reaction of fiber with an amino silane (Brochier Salon et al. 2005), (d) reaction of an amino silane-modified fiber with PVC (SelulosaPolivinilklorida et al. 2015) and (e) PC (Threepopnatkul et al. 2009), (f) reaction between vinyl silanemodified cellulose and PE matrix (Abdelmouleh et al. 2007), (g) acetylation of fibers (Mohit \& Arul Mozhi Selvan 2018), reaction of (h) mono and (i) diisocyanate with the cellulose fiber and polymer matrix (Abushammala \& Mao 2019), (j) grafting PGMA onto CNC through ATRP method (Le Gars et al. 2020), 
reaction of fiber with (k) maleated PE and (I) acrylic acid-functionalized PE (Rout et al. 2001), and (m) benzoylation of fibers (Sreekumar et al. 2009).

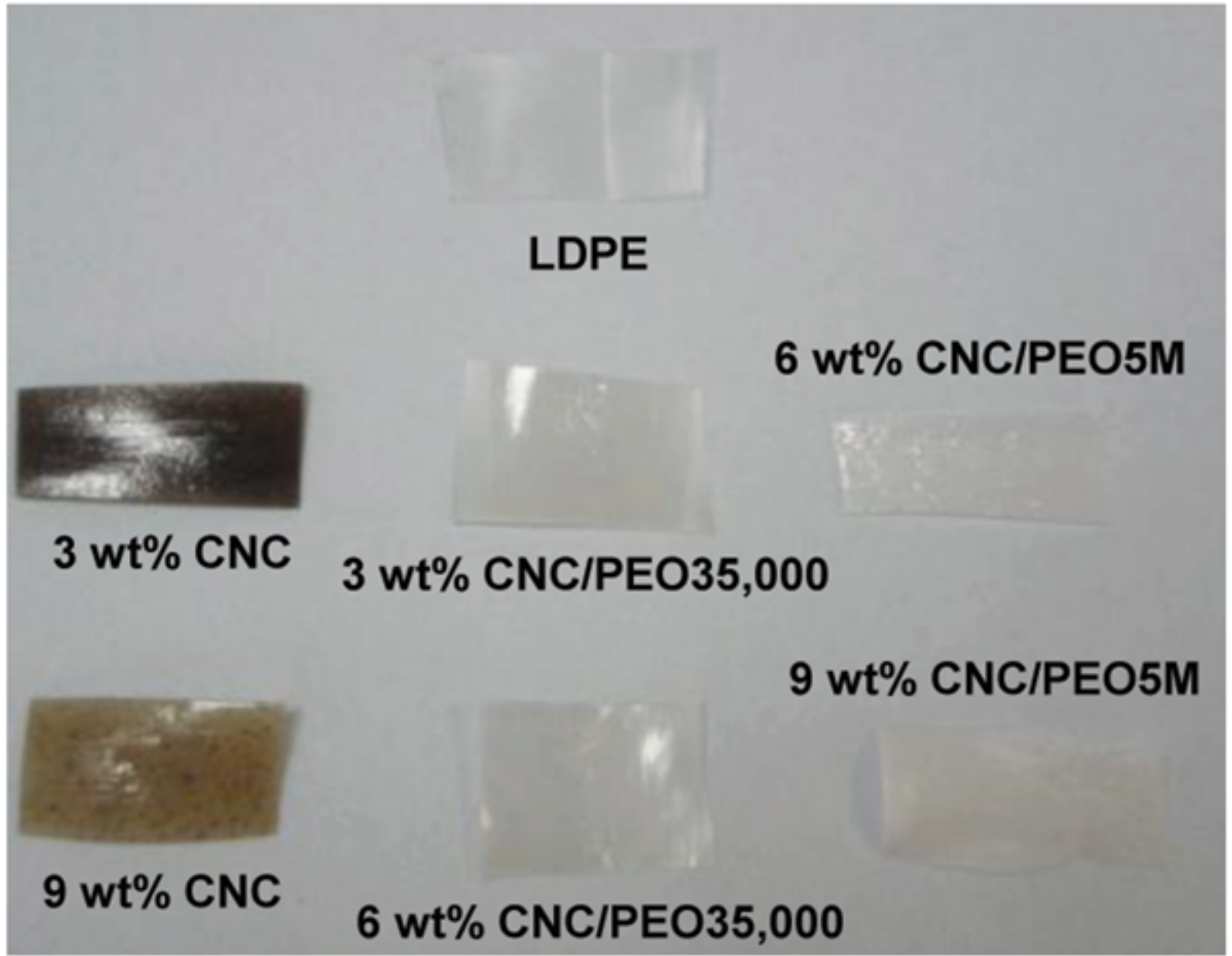

Figure 4 